\title{
Co-Activation of Epidermal Growth Factor Receptor and c-MET Defines a Distinct Subset of Lung Adenocarcinomas
}

\author{
Daisuke Matsubara, ${ }^{*}$ Shumpei Ishikawa, ${ }^{\dagger}$ \\ Oguni Sachiko, ${ }^{*}$ Hiroyuki Aburatani, ${ }^{\neq}$ \\ Masashi Fukayama, ${ }^{\dagger}$ and Toshiro Niki ${ }^{\star}$ \\ From the Department of Integrative Pathology, Jichi Medical \\ University, Shimotsuke, Tochigi; the Department of Human \\ Pathology, ${ }^{\dagger}$ Graduate School of Medicine, and the Division of \\ Genome Science, ${ }^{\ddagger}$ the Research Center for Advanced Science and \\ Technology, The University of Tokyo, Tokyo, Japan
}

Epidermal growth factor receptor (EGFR) and MET are molecular targets for lung cancer treatment. The relationships between expression, activation, and gene abnormalities of these two targets are currently unclear. Here, we demonstrate that a panel of 40 lung cancer cell lines could be classified into two groups. Group I was characterized by (1) high phosphorylations of MET and EGFR, (2) frequent mutation or amplification of EGFR, MET, and human epidermal growth factor receptor-2 (HER2), (3) high expressions of bronchial epithelial markers (thyroid transcription factor-1 (TTF-1), MUC1, and Cytokeratin 7 (CK7)); and (4) high expressions of MET, human epidermal growth factor receptor-3, E-cadherin, cyclooxygenase-2, and laminin gamma2. In contrast, Group II exhibited little or no phosphorylation of MET and EGFR; no mutation or amplification of EGFR, MET, and HER2; were triple-negative for TTF-1, MUC1, and CK7; and showed high expressions of vimentin, fibroblast growth factor receptor-1, and transcription factor 8. Importantly, Group I was more sensitive to gefitinib and more resistant to cisplatin and paclitaxel than Group II. The clinical relevance was confirmed in publicly available data on 442 primary lung adenocarcinoma patients; survival benefits by postoperative chemotherapy were seen in only patients with tumors corresponding to Group II. Overall, co-activation of EGFR and MET defines a distinct subgroup of lung carcinoma with characteristic genetic abnormalities, gene expression pattern, and response to chemotherapeutic reagents. (Am J Pathol 2010, 177:2191-2204; DOI: 10.2353/ajpath.2010.100217)

Lung cancer is the leading cause of cancer death in many developed countries, including the United States and
Japan. ${ }^{1,2}$ Patients with lung carcinoma have a poor prognosis: most have disease recurrence after complete surgical resection, and those with stage I disease have a 5-year survival of only $70 \% .{ }^{3}$ Among the four major histological types of lung cancer, adenocarcinoma has been rising in incidence in recent years ${ }^{4}$ and is a focus of intense investigations.

The discovery of the mutation of the epidermal growth factor receptor (EGFR) gene has been a major breakthrough in lung cancer. ${ }^{5}$ EGFR mutation is associated with adenocarcinoma histology, nonsmoking history, female sex, and clinical response to EGFR inhibitors. ${ }^{6}$ The short deletion of exon 19 and the point mutation of exon 21 are the most common of the EGFR mutations, together accounting for about $90 \%$ of the mutations overall. KRAS is another oncogene frequently mutated in lung adenocarcinoma. ${ }^{7}$ Mutations of KRAS and EGFR lead to enhanced activation of similar signaling pathways, such as AKT and ERK, and they occur in a mutually exclusive manner. ${ }^{5}$ Intriguingly, the EGFR mutation has reported associations with a bronchioloalveolar or papillary histological pattern, ${ }^{8}$ with the expression of thyroid transcription factor $-1,{ }^{9}$ and with micropapillary pattern, ${ }^{10,11}$ an aggressive variant of papillary adenocarcinoma. ${ }^{12,13}$ The KRAS mutation, on the other hand, is associated with mucinous histology. ${ }^{14}$ The genetic-histological correlations and mutually exclusive occurrence of EGFR and KRAS mutations suggest that it may be possible to classify lung adenocarcinomas based on integrated information on molecular abnormalities and histological patterns.

Supported in part by the Smoking Research Foundation, the Foundation for Development of Community, the Vehicle Racing Commemorative Foundation, and the Ministry of Health, Labor and Welfare, and the Ministry of Education, Culture, Sports, Science and Technology of Japan. Daisuke Matsubara is a recipient of Jichi Medical University Young Investigator Award. This publication was subsidized by Japan Keirin Association through its promotion funds from KEIRIN RACE.

Accepted for publication July 8, 2010.

T.N. and D.M. are recipients of the Astra-Zeneca research award 2007.

Supplemental material for this article can be found on http://ajp. amjpathol.org.

Address reprint requests to Toshiro Niki, M.D., Ph.D., Department of Integrative Pathology, Jichi Medical University, 3311-1 Yakushiji, Shimotsuke-shi, Tochigi, 329-0498, Japan. E-mail: tniki@jichi.ac.jp. 
Yet as of this writing, the associations of the adenocarcinoma subtypes with the various molecular mutations are still not entirely clear. Another recent study has shown high mutation rates of EGFR, KRAS, and BRAF in micropapillary lung adenocarcinomas, ${ }^{15}$ raising the possibility that the associations of the micropapillary morphology with various genetic mutations may differ between Western and Japanese populations. Further research to elucidate the genetichistological correlations and molecular classifications of lung adenocarcinomas is clearly warranted.

MET is another molecular target of potential relevance to lung adenocarcinomas. MET is highly expressed in nonsmall cell lung cancer, ${ }^{16,17,18}$ and its overexpression is associated with an advanced cancer stage and shorter patient survival. ${ }^{17,18}$ Our group recently investigated the expression and activation of MET in lung adenocarcinoma tissues and cell lines. ${ }^{19,20}$ MET overexpression and activation have been found in a significant proportion of lung adenocarcinomas, and they have been confirmed to be associated with papillary histology, a morphological feature linked to tumors with EGFR mutations. ${ }^{10,21}$ These results suggest that these two tyrosine kinase receptors may be closely related.

In this study we extended our prior investigations by analyzing a larger panel of lung cancer cell lines, mainly of lung adenocarcinomas. Specifically, we investigated the following molecular parameters and the possible relationships among them: (a) activation of EGFR and MET; (b) gene status of EGFR, MET and KRAS; and (c) gene expression profiles. We have found that adenocarcinoma cell lines could be classified into two groups based on integrated information on EGFR and MET abnormalities and the expression patterns of several genes, including thyroid transcription factor-1 (TTF-1). Importantly, these two groups of cell lines showed different sensitivities to gefitinib and chemotherapeutic agents. We have validated this classification by analyzing the gene expression pattern and survival of 442 lung adenocarcinoma patients. Thus, co-activation of EGFR and MET defines a distinct subgroup of lung carcinoma with characteristic genetic abnormalities, gene expression pattern, and response to chemotherapeutic reagents.

\section{Materials and Methods}

\section{Reagents}

PHA-665752 was kindly provided from Dr. J. Christensen, Pfizer. Gefitinib was generously provided by AstraZeneca. CL387,785 was purchased from Calbiochem (now Merck KGaA, Darmstadt, Germany). Paclitaxel and cisplatin were purchased from Enzo Life Sciences (Plymouth Meeting, PA) and LKT Laboratories (St. Paul, MN), respectively. Stock solutions of gefitinib and paclitaxel were prepared in dimethyl sulfoxide and stored at $-80^{\circ} \mathrm{C}$ until use. Stock solution of cisplatin was freshly prepared in $0.9 \% \mathrm{NaCl}$ for each experiment.

\section{Cell Lines and Medium}

We used 40 lung cancer cell lines. The sources and histological types of these cell lines are shown in Table $1 .{ }^{22}$ All cell lines were maintained in RPMl 1640 supplemented with $10 \%$ fetal calf serum, glutamine, and antibiotics in a humidified atmosphere with $5 \% \mathrm{CO}_{2}$ and $95 \%$ air.

\section{Antibodies}

The sources of the antibodies used in this study are summarized in Table 2. ${ }^{23}$

\section{DNA Sequencing}

The DNA was extracted from cell lines by standard procedures. The PCR primers and conditions for amplifying and sequencing exon 18 through exon 21 of the EGFR gene are described in the previous literature. ${ }^{24}$ The PCR primers and the conditions for mutational analysis of KRAS (codon 12, 13, and 61); MET (exon 2 and 3 encoding the Sema domain, and exon 14); and human epidermal growth factor-2 (HER2; exon 19 and 20) are not shown. The PCR products were sent to Macrogen Inc. (Seoul, Korea) and sequenced.

\section{Gene Expression Profile and Single Nucleotide Polymorphism Array Analyses}

A comprehensive gene expression analysis was performed using an oligonucleotide microarray (GeneChip Human Genome U133A, Affymetrix, Santa Clara, CA) as described previously. $25,26,27$ Single nucleotide polymorphism array (Affymetrix human mapping 50K Xbal array) analysis was performed using GIM (Genome Imbalance Map) algorithm as described previously. ${ }^{28}$

\section{Western Blot Analysis}

Cells were lysed in a lysis buffer consisting of $20 \mathrm{mmol} / \mathrm{L}$ Tris-HCl (pH7.4), $150 \mathrm{mmol} / \mathrm{L} \mathrm{NaCl}, 50 \mathrm{mmol} / \mathrm{L} \mathrm{NaF}$, and 1 $\mathrm{mmol} / \mathrm{L} \mathrm{Na3VO} 4$ with a cocktail of proteinase inhibitors. After sonication, lysates were boiled at $98^{\circ} \mathrm{C}$ for 5 minutes and cleared by centrifugation. Protein concentrations were determined by the DC Protein Assay kit (BioRad). For Western blotting, equal amounts of protein samples were sizeseparated on $8 \%$ polyacrylamide gels and electroblotted onto nitrocellulose membrane. Nonspecific binding was blocked by immersion of the membranes for 20 minutes in $5 \%$ skim milk in Tris-buffer saline at room temperature. The membranes were washed with Tris-buffer saline buffer containing $0.1 \%$ Tween 20 , incubated for 1 hour at room temperature with primary antibodies, washed, and then reacted with peroxidase-conjugated secondary antibodies. The antigen was detected using ECL Western Blotting Detection Reagents (Amersham) following the manufacture's instructions.

\section{Bioinformatic Analyses}

We used the Cluster program (http://rana.lbl.gov/ EisenSoftware.htm, last accessed on March 19, 2008) for cluster analysis of the gene expression data of cell 
Table 1. Histological Types and Sources of 40 Lung Carcinoma Cell Lines

\begin{tabular}{|c|c|c|}
\hline Cell line & Histological type & Source \\
\hline H23 & Adenocarcinoma cell line & ATCC $^{*}$ \\
\hline $\mathrm{H} 292$ & Adenocarcinoma cell line & ATCC \\
\hline H358 & Adenocarcinoma cell line & ATCC \\
\hline $\mathrm{H} 441$ & Adenocarcinoma cell line & ATCC \\
\hline H522 & Adenocarcinoma cell line & ATCC \\
\hline $\mathrm{H} 650$ & Adenocarcinoma cell line & ATCC \\
\hline $\mathrm{H} 1395$ & Adenocarcinoma cell line & ATCC \\
\hline $\mathrm{H} 1648$ & Adenocarcinoma cell line & ATCC \\
\hline H1650 & Adenocarcinoma cell line & ATCC \\
\hline $\mathrm{H} 1651$ & Adenocarcinoma cell line & ATCC \\
\hline $\mathrm{H} 1703$ & Adenocarcinoma cell line & ATCC \\
\hline $\mathrm{H} 1781$ & Adenocarcinoma cell line & ATCC \\
\hline $\mathrm{H} 1793$ & Adenocarcinoma cell line & ATCC \\
\hline $\mathrm{H} 1838$ & Adenocarcinoma cell line & ATCC \\
\hline H1975 & Adenocarcinoma cell line & ATCC \\
\hline H1993 & Adenocarcinoma cell line & ATCC \\
\hline H2OO9 & Adenocarcinoma cell line & ATCC \\
\hline $\mathrm{H} 2087$ & Adenocarcinoma cell line & ATCC \\
\hline $\mathrm{H} 2228$ & Adenocarcinoma cell line & ATCC \\
\hline $\mathrm{H} 2405$ & Adenocarcinoma cell line & ATCC \\
\hline HCC827 & Adenocarcinoma cell line & ATCC \\
\hline HCC4006 & Adenocarcinoma cell line & ATCC \\
\hline Calu3 & Adenocarcinoma cell line & ATCC \\
\hline A549 & Adenocarcinoma cell line & Japanese Cancer Research Resources Bank (Osaka, Japan) \\
\hline$A B C-1$ & Adenocarcinoma cell line & Japanese Cancer Research Resources Bank (Osaka, Japan) \\
\hline PC3 & Adenocarcinoma cell line & Japanese Cancer Research Resources Bank (Osaka, Japan) \\
\hline VMRC-LCD & Adenocarcinoma cell line & Japanese Cancer Research Resources Bank (Osaka, Japan) \\
\hline RELF-LC-Ad1 & Adenocarcinoma cell line & Japanese Cancer Research Resources Bank (Osaka, Japan) \\
\hline RELF-LC-Ad2 & Adenocarcinoma cell line & Japanese Cancer Research Resources Bank (Osaka, Japan) \\
\hline RELF-LC-MS & Adenocarcinoma cell line & Japanese Cancer Research Resources Bank (Osaka, Japan) \\
\hline HLC-1 & Adenocarcinoma cell line & RIKEN Cell Bank (Tsukuba, Japan) \\
\hline LC-2/ad & Adenocarcinoma cell line & RIKEN Cell Bank (Tsukuba, Japan) \\
\hline PC14 & Adenocarcinoma cell line & RIKEN Cell Bank (Tsukuba, Japan) \\
\hline RERF-LC-KJ & Adenocarcinoma cell line & Japanese Cancer Research Resources Bank (Osaka, Japan) \\
\hline L27 & Adenocarcinoma cell line & $\begin{array}{l}\text { A kind gift from Dr. S. Hirohashi, National Cancer Center Institute, } \\
\text { Tokyo, Japan, as described in a previous study (22) }\end{array}$ \\
\hline H596 & Adenosquamous cell line & ATCC \\
\hline $\mathrm{H} 460$ & Large cell carcinoma cell line & ATCC \\
\hline $\mathrm{H} 661$ & Large cell carcinoma cell line & ATCC \\
\hline H1299 & Large cell carcinoma cell line & ATCC \\
\hline Lu65 & Large cell carcinoma cell line & Japanese Cancer Research Resources Bank (Osaka, Japan) \\
\hline
\end{tabular}

*ATCC, American Type Culture Collection.

lines and lung adenocarcinoma cases. In brief, we performed average linkage hierarchical clustering of 40 cell lines, using median centering, mean centering and normalization of genes, and we performed average linkage hierarchical clustering of 442 lung adenocarcinoma cases, using median centering and mean centering of genes. Next we displayed the results with the aid of TreeView software (http://rana./bl.gov/EisenSoftware.htm,

Table 2. Antibodies Used in Western Blot Analysis

\begin{tabular}{lll}
\hline \multicolumn{1}{c}{ Antibodies } & \multicolumn{1}{c}{ Clone } & \multicolumn{1}{c}{ Sources } \\
\hline C-MET & Rabbit polyclonal & IBL (Gunma, Japan) \\
COX2 & Rabbit polyclonal & IBL (Gunma, Japan) \\
EGFR (\#2232) & Rabbit polyclonal & Cell Signaling Technology (Danvers, MA) \\
Phospho-EGFR (Y1068) (\#2234) & Rabbit polyclonal & Cell Signaling Technology (Danvers, MA) \\
Phospho-c-MET(Y1234/Y1235) & Rabbit polyclonal & Cell Signaling Technology (Danvers, MA) \\
TTF-1 (clone 8G7G3/1) & Mouse monoclonal & DAKO (Glostrup, Denmark) \\
Cytokeratin 7 (clone OV-TL 12/30) & Mouse monoclonal & DAKO (Glostrup, Denmark) \\
Vimentin (clone V9) & Mouse monoclonal & DAKO (Glostrup, Denmark) \\
E-cadherin (clone 36) & Mouse monoclonal & BD Biosciences (Franklin Lakes, NJ) \\
P-cadherin (clone 56) & Mouse monoclonal & BD Biosciences (Franklin Lakes, NJ) \\
MUC1 smaller cytoplasmic subunit & Hamster monoclonal & Lab Vision (Cheshire, UK) \\
Laminin gamma2 & Mouse monoclonal & Described in a previous study (23) \\
Anti-rabbit IgG peroxidase conjugate & Amersham (Arlington Heights, IL) \\
Anti-mouse IgG peroxidase conjugate & & Amersham (Arlington Heights, IL) \\
Anti-Armenian hamster lgG peroxidase conjugate & & Jackson Immunoresearch (West Grove, PA) \\
\hline
\end{tabular}


last accessed on March 21, 2008). The image used a color code to represent relative expression levels. Red represents expression levels greater than the mean for a given gene across all samples. Green represents expression levels less than the mean across samples.

\section{Cell Proliferation Assay}

Cell viability was measured by the Cell Counting Kit (CCK) -8 assay (Dojindo, Tokyo, Japan) according to the manufacturer's instructions. Cells $(4 \sim 8 \times 103$ cells $)$ were plated in the wells of 96-well microtiter plates. After 24 hours, paclitaxel, cisplatin, and gefitinib were added respectively to the wells at the following final concentrations: $3.3 \mu \mathrm{mol} / \mathrm{L}, 1 \mu \mathrm{mol} / \mathrm{L}, 0.1 \mu \mathrm{mol} / \mathrm{L}, 0.01 \mu \mathrm{mol} / \mathrm{L}$, and $0.01 \mu \mathrm{mol} / \mathrm{L}$ for paclitaxel; $50 \mu \mathrm{mol} / \mathrm{L}, 10 \mu \mathrm{mol} / \mathrm{L}, 3.3$ $\mu \mathrm{mol} / \mathrm{L}, 1 \mu \mathrm{mol} / \mathrm{L}, 0.1 \mu \mathrm{mol} / \mathrm{L}$, and $0.01 \mu \mathrm{mol} / \mathrm{L}$, for cisplatin; and $10 \mu \mathrm{mol} / \mathrm{L}, 3.3 \mu \mathrm{mol} / \mathrm{L}, 1 \mu \mathrm{mol} / \mathrm{L}, 0.1$ $\mu \mathrm{mol} / \mathrm{L}, 0.01 \mu \mathrm{mol} / \mathrm{L}$, and $0.001 \mu \mathrm{mol} / \mathrm{L}$, for gefitinib. The cells were then incubated for another 4 days at $37^{\circ} \mathrm{C}$. The absorbance of each well at $450 \mathrm{~nm}$ was measured with a reference at $630 \mathrm{~nm}$ using a BIO-RAD model 680XR microplate reader (Bio-Rad, Hercules, CA). The percentage of cell viability was calculated by following formula: \%cell viability $=($ mean absorbance in test wells)/(mean absorbance in control well $) \times 100$. Results were plotted as cell viability versus log10 (concentration of reagents) and IC50 value was calculated using a software GraphPad Prism 5 (GraphPad Software, Inc., CA).

\section{Statistics}

Clinicopathological correlations were analyzed by one-factor analysis of variance and Fisher's PLSD (post hoc) tests after converting T-stage, $\mathrm{N}$-stage, pathological stage, differentiation grade, and smoking history to ordinal scale data. The calculations were done with StatView (Abacus Concepts, Berkeley, CA). $P$ values of less than 0.05 were considered statistically significant. Survival curves were generated using the Kaplan-Meier method and differences in survival were analyzed by the Wilcoxon method.

\section{Results}

\section{Activation of EGFR and MET in Cell Lines of Lung Adenocarcinoma}

First, we examined a panel of 18 cell lines of lung carcinoma by Western blot analysis to determine the activation of EGFR and MET. The cell lines consisted of 16 adenocarcinomas and 2 large cell carcinomas, derived from cell banks in the United States and Japan. The results are shown in Figure 1 (lower panel). MET was activated at high levels in 6 cell lines (L27, H1648, PC3, H1975, $\mathrm{H} 2009$, and LC-2/ad) and at weak levels in several other lines. Similarly, EGFR was activated at high levels in 7 cell lines (L27, H1648, PC3, H1650, H1975, H2009, and LC2/ad) and at modest levels in several others. Close examination of genetic status of EGFR, MET and KRAS

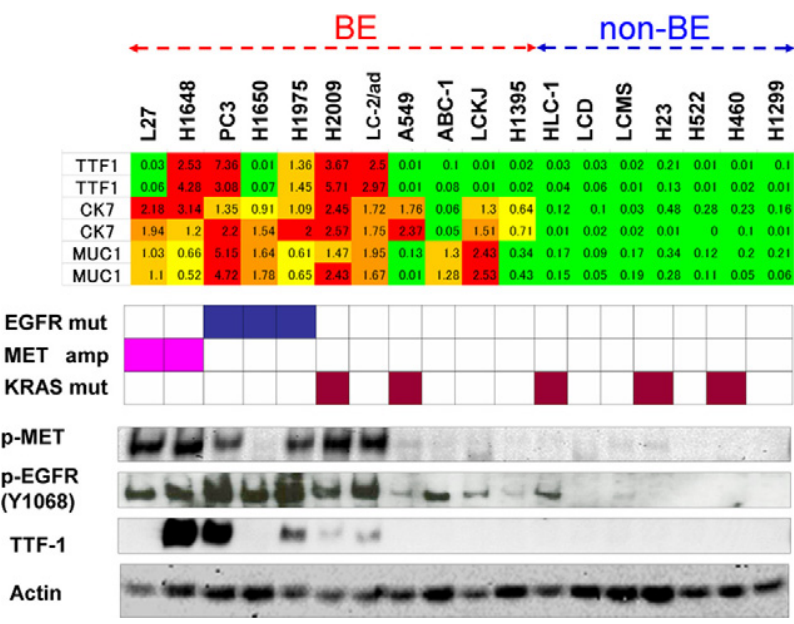

Figure 1. Comparison of MUC1, CK7, and TTF-1 expression levels with the status of EGFR, MET, and KRAS and the activation profiles of EGFR and MET in a panel of lung carcinoma cell lines. Upper panel shows the gene expression levels of MUC1, CK7, and TTF-1 expressed to relative to the average $(=1.0)$ of 18 cell lines, and color indication is as described for supplemental Table S1 at http://ajp.amjpathol.org. Middle panel shows cell lines harboring EGFR mutation (blue box), MET amplification (pink box), and KRAS mutation (brown box) Lower panel shows the protein levels of phospho-MET, phospho-EGFR (Y1068), and TTF-1 expression (This lower panel is rearranged in Figure 3C, Figure 3D, and supplemental Figure S1B at http://ajp.amjpathol.org.). MET was highly phosphorylated in 6 cell lines (L27, H1648, PC3, H1975, H2009, and LC-2/ad), and EGFR was highly phosphorylated in seven cell lines (L27, H1648, PC3, H1650, H1975, H2009, and LC-2/ad). Thus, a striking overlap was noted between activation profiles of EGFR and MET. TTF-1 expression was correlated with EGFR and MET activation, but the cell lines that express TTF-1 were more restricted than those that express phospho-MET or phospho-EGFR (Y1068) at high levels. Thus, the cell lines may be broadly divided into two groups; bronchial epithelial phenotype (BE) and non-bronchial epithelial phenotype (non-BE) based on expression levels of MUC1, CK7, and TTF-1 and the activation profiles of EGFR and MET.

(middle panel) and the activation profiles of EGFR and MET (lower panel) in Figure 1 revealed a number of interesting findings. First, although EGFR and MET were highly activated in the cell lines with EGFR mutation and MET amplification, respectively, these gene abnormalities were not the sole determinants of the activation status of the two receptors. Second, EGFR mutation, KRAS mutation, and MET amplification were mutually exclusive. Third, a striking overlap was noted between activation profiles of EGFR and MET: all of the five cell lines with high MET activation showed high activation of EGFR. Fourth, as a result of this overlap, the cell lines with activation of EGFR and MET appeared to constitute a subgroup among the cell lines examined. These findings were largely confirmed through analyses of another panel of lung cancers consisting of 19 cell lines of adenocarcinoma, 2 cell lines of large cell carcinoma, and 1 cell line of adenosquamous carcinoma (See Supplemental Figure S1A at $h$ ttp://ajp.amjpathol.org).

We were especially interested in the striking overlap between the activation profiles of EGFR and MET, as it implied the existence of a molecularly defined subgroup of lung adenocarcinomas. According to a recently proposed molecular classification of lung adenocarcinomas based on TTF-1 expression, TTF-1-positive tumors have the features of terminal respiratory units (TRUs) and are associated with EGFR mutation and sensitivities to EGFR inhibitor gefitinib. ${ }^{9}$ To investigate further, we examined 
TTF-1 expression in our panel of cell lines by Western blot analysis. The results are shown in Figure 1 (lower panel) and supplemental Figure S1B at http://ajp.amjpathol.org. Though TTF-1 expression was clearly correlated with EGFR and MET activation, the cell lines defined by TTF-1 expression did not completely match those defined by EGFR and MET activation.

These results prompted us to search for markers that may correlate with high activation of EGFR and MET. In combination with TTF-1, the markers that correlate with high activation of EGFR and MET may turn out to be useful markers in the molecular classification of lung adenocarcinoma cell lines.

\section{The Expressions of TTF-1, Cytokeratin 7, and MUC1 Genes Correlate with the Activation of EGFR and MET}

In our search for markers correlated with EGFR and MET activation, we turned to classical histopathological markers, ie, the cytokeratin and MUC families. ${ }^{29,30}$ Both of these gene families have been used in numerous histopathological studies to characterize various types of cancer, including lung adenocarcinomas. ${ }^{31,32,33}$ Noting this, we reasoned that expression data on these families, together with data on TTF-1 expression, would provide fundamental information on the properties of lung adenocarcinoma cells. Toward this end, we extracted expression profile data for the cytokeratin and MUC family genes and examined the relative expression levels of these genes in the cell lines. The results are shown in the heat-map in supplemental Table S1 at $h$ ttp://ajp.amjpathol. org. According to the correlation coefficients, the expressions of MUC1, MUC4, cytokeratin 7 (CK7), cytokeratin 16 (CK16), cytokeratin 17 (CK17), and cytokeratin 19 (CK19) were high in the six cell lines in which co-activation of EGFR and MET was detected (L27, H1648, PC3, H1975, H2009, and LC-2/ad). We chose MUC1 and CK7, a pair of histopathological markers frequently used for lung adenocarcinomas, for further analysis. The gene expressions of TTF-1, CK7, and MUC1 are shown in Figure 1 (upper panel). Seven cell lines with high levels of EGFR and MET activation and high level expression of TTF-1, CK7, and MUC1 (L27, H1648, PC3, H1650, $\mathrm{H} 1975, \mathrm{H} 2009$, and LC-2/ad) and 7 cell lines with negligible activation of EGFR and MET and low level expression of TTF-1, CK7, and MUC1 (HLC-1, VMRC-LCD, RELF-LCMS, H23, H522, H460, and H1299) appeared to form as two distinct groups. Another four cell lines (A549, ABC1, RELF-LCKJ, and H1395), meanwhile, were intermediate between the former two. The first seven cell lines with high level expression of TTF-1, CK7, and MUC1, and four intermediate cell lines with modest level expression of them were tentatively combined and designated as bronchial epithelial phenotype, and the remainder with negligible level expression of them were designated as nonbronchial epithelial phenotype. High level activation and genetic abnormalities of MET and EGFR were observed only in bronchial epithelial phenotype. The broad separation of cell lines into two groups was largely con- firmed using another panel of 22 lines of lung cancer cells. The results on the entire panel of 40 cell lines are shown in supplemental Figure S1B at $h$ ttp://ajp.amjpathol.org.

\section{Genes Expression Pattern Characterizing the Two Phenotypes of Cell Lines}

Previous studies have documented a list of genes whose expressions correlate with the classifications for lung adenocarcinomas ${ }^{34,35}$. Yet many of the genes included in lists of this type have functions heretofore unknown. For this reason, it remains to be seen whether gene lists will improve our understanding of the biological properties of lung adenocarcinomas. As an alternative, we focused on a family of genes whose functions have been well characterized in cancer cell biology: tyrosine kinase receptors, cadherins, integrins, proteinases, molecules related to prostaglandin synthesis, extracellular matrix molecules such as collagens and laminins, and genes related to epithelial-mesenchymal transition. The numbers of genes and probes sets retrieved for analysis are shown in supplemental Table S2 at http://ajp.amjpathol.org, and the comprehensive dataset for the expression profiles of these families is shown in supplemental Table S3 at $h$ ttp:// ajp.amipathol.org. Next, we calculated the correlation coefficients of TTF-1, CK7, and MUC1, as well as the mean value of the three coefficients, for each gene. We also determined the mean expression ratio between the cell lines in bronchial epithelial phenotype and nonbronchial epithelial phenotype for each gene. Finally, we selected the genes which met the following two requirements: $(A)$ the absolute value of the mean correlation coefficient exceeds 0.3 , and (B) the mean expression ratio of bronchial epithelial phenotype versus nonbronchial epithelial phenotype is greater than 3 or less than $1 / 3$. The results are shown in Table 3. To illustrate the differential expression of these genes, the expression levels of the several selected genes are shown in the bar graphs in Figure 2A. Bronchial epithelial phenotype was characterized by high expressions of MET, human epidermal growth factor receptor-3 (HER3), integrin beta6, E-cadherin, P-cadherin, urokinase-type plasminogen activator (u-PA), cyclooxygenase-2 (Cox-2), and laminin gamma2. In contrast, non-bronchial epithelial phenotype showed a high expression of vimentin, fibroblast growth factor receptor-1 (FGFRI), and transcription factor 8 (TCF-8) (also called Zeb1).

Next, we tried to confirm whether these genes expression patterns of bronchial epithelial phenotype and nonbronchial epithelial phenotype cell lines were reflected in corresponding protein levels. For this purpose, we chose MET, HER3, E-cadherin, P-cadherin, Cox-2, and laminin gamma2, the genes with antibodies available for Western blotting. As shown in Figure 2B, Western blot analysis largely confirmed the data obtained at the mRNA level by oligonucleotide array analysis.

\section{Hierarchical Cluster Analysis of Cell Lines}

We performed a hierarchical cluster analysis of the initial 18 lung cancer cell lines (16 adenocarcinoma and 2 large 
Table 3. Genes Selectively Expressed as Bronchial Epithelial Phenotype or Nonbronchial Epithelial Phenotype (BE/non-BE $>3$ or $<1 / 3$ ), Showing Positive or Negative Correlations with the Expression of CK7, TTF1, and MUC1 (Correlation Coefficient $>0.3$ or $<-0.3)$

\begin{tabular}{|c|c|c|c|c|}
\hline Gene & CORREL & BE/non-BE & BE (avg) & Non-BE (avg) \\
\hline \multicolumn{5}{|l|}{ TKRs } \\
\hline MET & 0.46 & 4.6 & 1460 & 316 \\
\hline ERBB3 & 0.39 & 3.6 & 470 & 132 \\
\hline$R O R 1$ & 0.64 & 5.7 & 125 & 22 \\
\hline EPHB2 & 0.55 & 4.4 & 138 & 31.6 \\
\hline EPHB3 & 0.71 & 8.1 & 61.7 & 7.59 \\
\hline EPHA1 & 0.63 & 6.5 & 120 & 18.6 \\
\hline FGFR1 & -0.32 & 0.31 & 54 & 174 \\
\hline \multicolumn{5}{|l|}{ MUCs } \\
\hline MUC1 & 0.71 & 14 & 770 & 57.1 \\
\hline MUC4 & 0.50 & 40 & 173 & 4.32 \\
\hline MUC16 & 0.61 & 5.3 & 88.5 & 16.8 \\
\hline MUC20 & 0.38 & 36 & 283 & 7.81 \\
\hline \multicolumn{5}{|l|}{ Keratins } \\
\hline KRT4 & 0.50 & 29 & 349 & 12.2 \\
\hline$K R T 7$ & 0.68 & 80 & 2910 & 36.4 \\
\hline KRT13 & 0.53 & 33 & 95.6 & 2.89 \\
\hline KRT15 & 0.62 & 7.9 & 135 & 17.1 \\
\hline KRT19 & 0.59 & 5.4 & 4920 & 920 \\
\hline \multicolumn{5}{|l|}{ Growth factors } \\
\hline TGFA & 0.57 & 6.6 & 413 & 62.4 \\
\hline VEGFC & 0.54 & 4.1 & 250 & 60.8 \\
\hline INHBB & 0.53 & 19 & 414 & 21.7 \\
\hline IGFBP6 & 0.46 & 6.8 & 466 & 68.5 \\
\hline TGFBI & 0.43 & 4.4 & 4020 & 910 \\
\hline AREG & 0.33 & 7.4 & 738 & 99.7 \\
\hline BMP4 & 0.42 & 7.7 & 63.2 & 8.2 \\
\hline WNT7B & 0.57 & 6.8 & 50.8 & 7.51 \\
\hline \multicolumn{5}{|l|}{ Eicosanoids } \\
\hline PTGES & 0.40 & 5.5 & 419 & 76.6 \\
\hline PTGFRN & 0.39 & 4.8 & 403 & 83.3 \\
\hline PTGS2 (COX2) & 0.33 & 11 & 319 & 29.9 \\
\hline \multicolumn{5}{|l|}{ Rho-Racs } \\
\hline RAC2 & 0.55 & 56 & 663 & 11.8 \\
\hline RHOD & 0.48 & 3.3 & 431 & 131 \\
\hline \multicolumn{5}{|l|}{ Proteinases } \\
\hline MMP1 & 0.31 & 8.3 & 810 & 97.1 \\
\hline CTSS & 0.66 & 30 & 152 & 5.07 \\
\hline PLAT & 0.61 & 21 & 1360 & 63.9 \\
\hline PLAU & 0.54 & 4.3 & 1140 & 264 \\
\hline \multicolumn{5}{|c|}{ Cadherin-associated } \\
\hline $\mathrm{CDH} 1$ & 0.54 & 9.3 & 2640 & 285 \\
\hline $\mathrm{CDH} 6$ & 0.52 & 3 & 57.9 & 19.3 \\
\hline $\mathrm{CDH} 3$ & 0.51 & 19 & 987 & 52.6 \\
\hline PCDH1 & 0.53 & 6.6 & 68.7 & 10.4 \\
\hline \multicolumn{5}{|l|}{ Integrins } \\
\hline ITGB2 & 0.73 & 13 & 75.1 & 5.8 \\
\hline ITGB4 & 0.61 & 5.1 & 280 & 55.2 \\
\hline ITGB6 & 0.68 & 43 & 116 & 2.67 \\
\hline \multicolumn{5}{|l|}{ Laminins } \\
\hline LAMA3 & 0.60 & 6.8 & 241 & 35.5 \\
\hline LAMC2 & 0.70 & 28 & 395 & 8.1 \\
\hline$\angle A M B 3$ & 0.53 & 5.8 & 749 & 129 \\
\hline LAMA1 & -0.30 & 0.018 & 6.63 & 372 \\
\hline \multicolumn{5}{|l|}{ Collagens } \\
\hline COL18A1 & 0.43 & 3.8 & 51.5 & 13.7 \\
\hline COL5A2 & -0.34 & 0.022 & 30.4 & 1350 \\
\hline \multicolumn{5}{|l|}{ EMTs } \\
\hline JUP & 0.55 & 3.1 & 857 & 278 \\
\hline SNAI2 & 0.47 & 7.6 & 210 & 27.7 \\
\hline SMAD3 & 0.46 & 3.3 & 216 & 64.7 \\
\hline TGFBR2 & 0.44 & 5.4 & 694 & 128 \\
\hline CLDN4 & 0.71 & 8.5 & 354 & 41.8 \\
\hline CLDN7 & 0.46 & 14 & 991 & 72 \\
\hline VIM & -0.38 & 0.32 & 1780 & 5660 \\
\hline TCF8 & -0.56 & 0.161 & 15.4 & 95.6 \\
\hline
\end{tabular}


A
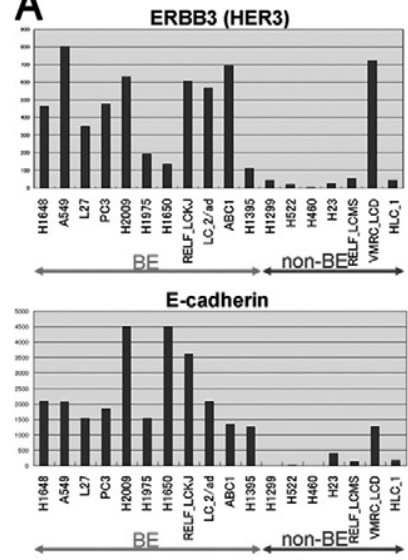

Lamnin-5 gamma2

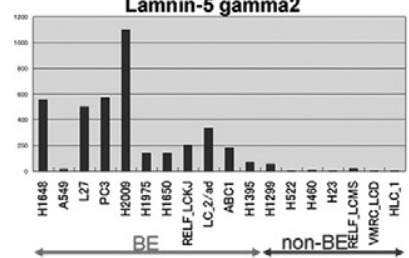

Integrin beta6
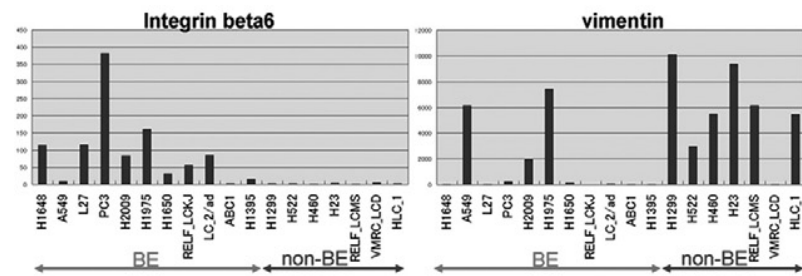

B

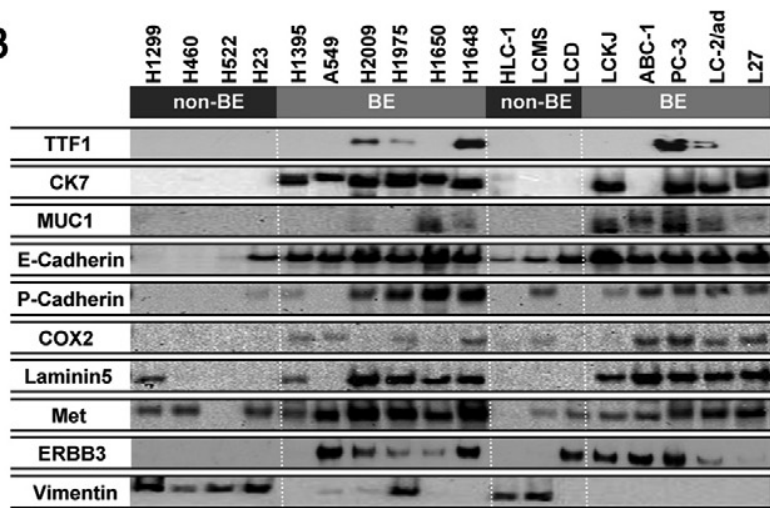

Figure 2. A: Genes selectively expressed in the bronchial epithelial phenotype (BE) and nonbronchial epithelial phenotype (non-BE). The expression levels of the indicated genes are shown in the bar graphs. B: Western blot analysis of the gene products selectively expressed in the bronchial epithelial phenotype (BE) and non-bronchial epithelial phenotype (non-BE). The results largely confirmed the data obtained at the mRNA level by oligonucleotide array analysis.

cell carcinoma) using the genes selectively expressed in the bronchial epithelial phenotype and nonbronchial epithelial phenotype cell lines. The results are shown in Figure 3A and C. Eighteen cell lines were classified into two groups; Group I and Group II. Group I and Group II nearly correspond to bronchial epithelial phenotype and nonbronchial epithelial phenotype, respectively, but the former classification seems to be more closely correlated with the genetic abnormality and the activation of EGFR and MET than the latter. As expected, the genes selec- tively expressed in the bronchial epithelial phenotype and non-bronchial epithelial phenotype cell lines of our initial panel clustered with the corresponding groups. These results were mostly confirmed using the entire panel of 40 cell lines ( 35 cell lines of adenocarcinoma, 4 cell lines of large cell carcinoma, and 1 cell line of adenosquamous carcinoma) (Figure 3, B and D). The gene expression data of another panel of 22 cell lines for hierarchical cluster analysis is shown in supplemental Table S4 at http://ajp.amjpathol.org. Interestingly, not only EGFR mutation and MET amplification, but also EGFR amplification, MET mutation, HER2 amplification, and HER2 mutation were concentrated in Group I. MET was reported to interact with both EGFR and HER2. ${ }^{36}$ These results suggest that cross talk between the EGFR pathway and the MET pathway might occur in Group I cell lines, and that co-activation of EGFR and MET might be associated with genetic abnormalities of EGFR, MET, and HER2.

\section{Effects of PHA665752 (MET Inhibitor) and CL387,785 (Dual EGFR/HER2 Inhibitor) on Phospho-MET and Phospho-EGFR}

We tested the effects of PHA665752 (MET inhibitor) treatment and CL387,785 (dual EGFR/HER2 inhibitor) treatment on the phosphorylation of MET and EGFR in three Group I cell lines: H1993 with MET amplification, HCC827 with EGFR mutation/amplification, and Calu-3 with HER2 amplification. The results are shown in supplemental Figure 2 at http://ajp.amjpathol.org. PHA665752 $\left(1 \times 10^{-6}\right.$ $\mathrm{mol} / \mathrm{L})$ suppressed the constitutive MET phosphorylation in the three cell lines and abolished the baseline phosphorylation of EGFR in H1993. It was significant that PHA665752 at this concentration conferred the latter effect. Conversely, CL387,785 $\left(1 \times 10^{-6} \mathrm{~mol} / \mathrm{L}\right)$ suppressed the expressions and phosphorylation of both EGFR and MET in HCC827 and Calu-3. These results suggest that the MET and EGFR activations may occur reciprocally via either MET amplification, EGFR mutation, or HER2 amplification. The baseline phosphorylation of EGFR in HCC827 and Calu-3 was unaffected by PHA665752. This was expected, as EGFR activation is dependent on either EGFR or HER2 in these two cell lines.

\section{Hierarchical Cluster Analysis of Primary Tumors}

To further validate the relevance of this classification in primary tumors, we performed hierarchical cluster analysis using publicly available data of 442 primary lung adenocarcinoma cases, ${ }^{37}$ using the genes selectively expressed in Group I and Group II. As shown in Figure $4 \mathrm{~A}$, primary lung adenocarcinoma cases were divided into three clusters (Cluster $A, B$, and $C$ ), reflecting the intertumoral heterogeneity of primary tumors as compared to cell lines. Cluster A and Cluster B differentially expressed a subset of genes selectively expressed in Group I. Cluster A showed high expression of bronchial epithelial markers (CK7, TTF-1, and E-cadherin), whereas 
A

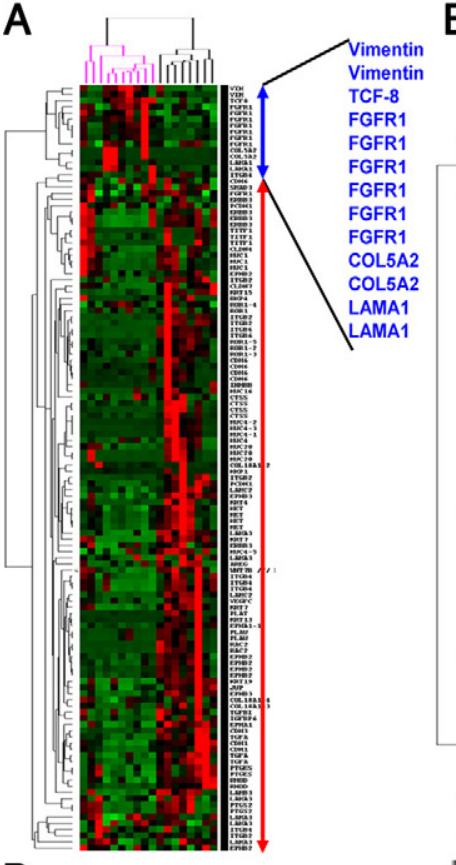

D

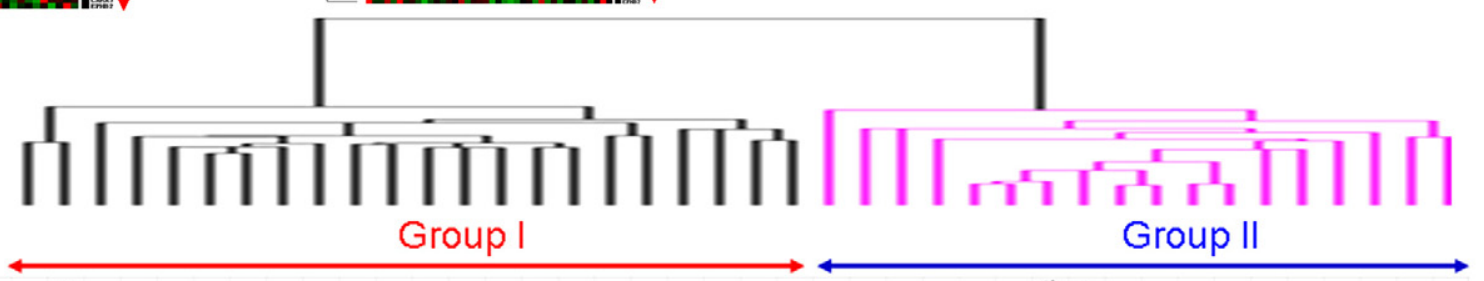

B

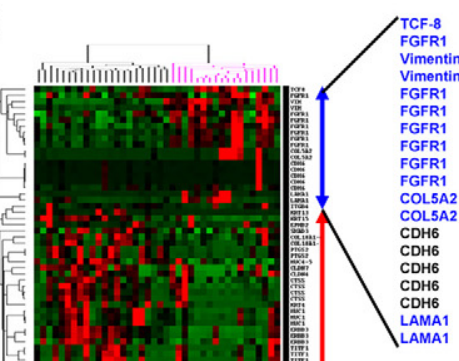

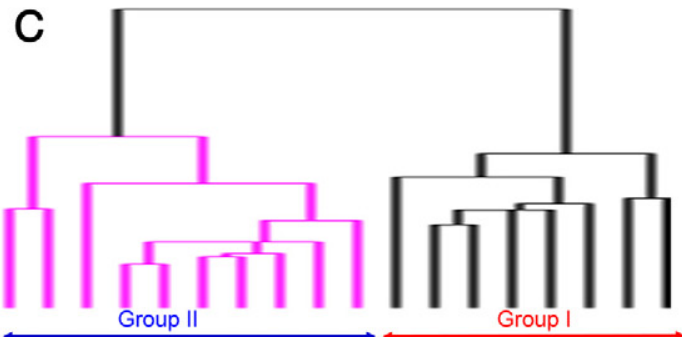

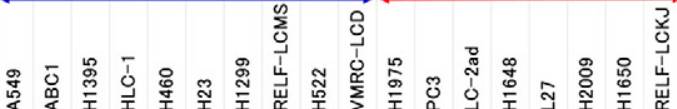

$\begin{array}{lllllllllllllllllll}\text { TTF1 } & 0.01 & 0.1 & 0.02 & 0.03 & 0.01 & 0.21 & 0.1 & 0.02 & 0.01 & 0.03 & 1.36 & 7.36 & 2.5 & 2.53 & 0.03 & 3.67 & 0.01 & 0.01 \\ \text { TTF1 } & 0.01 & 0.08 & 0.02 & 0.04 & 0.02 & 0.13 & 0.01 & 0.01 & 0.01 & 0.06 & 1.45 & 3.08 & 2.97 & 4.28 & 0.06 & 5.71 & 0.07 & 0.01\end{array}$

$\begin{array}{lllllllllllllllllll}\text { TTF1 } & 0.01 & 0.08 & 0.02 & 0.04 & 0.02 & 0.13 & 0.01 & 0.01 & 0.01 & 0.06 & 1.45 & 3.08 & 2.97 & 4.28 & 0.06 & 5.71 & 0.07 & 0.01 \\ \text { CK7 } & 1.76 & 0.06 & 0.64 & 0.12 & 0.23 & 0.48 & 0.16 & 0.03 & 0.28 & 0.1 & 1.09 & 1.35 & 1.72 & 3.14 & 2.18 & 2.45 & 0.91 & 1.3\end{array}$

$\begin{array}{llllllllllllllllllll}\text { CK7 } & 2.37 & 0.05 & 0.71 & 0.01 & 0.1 & 0.01 & 0.01 & 0.02 & 0 & 0.02 & 2 & 22 & 1.75 & 1.2 & 1.94 & 257 & 1.54 & 1.51\end{array}$ $\begin{array}{lllllllllllllllllllll}\text { MUC1 } & 0.13 & 1.3 & 0.34 & 0.17 & 0.2 & 0.34 & 0.21 & 0.17 & 0.12 & 0.09 & 0.61 & 5.15 & 1.95 & 0.66 & 1.03 & 1.47 & 1.64 & 2.1\end{array}$ \begin{tabular}{l|l|l|lllllllllllllllllll} 
MUC1 & 0.01 & 1.28 & 0.43 & 0.15 & 0.05 & 0.28 & 0.06 & 0.19 & 0.11 & 0.05 & 0.65 & 472 & 1.67 & 0.52 & 1.1 & 2.43 & 1.78 & 25
\end{tabular}

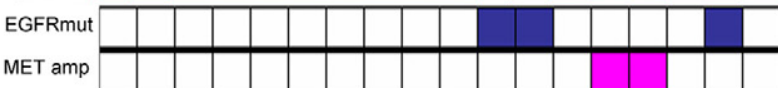

P-MET p-EGFR $\rightarrow-\infty . .0$ | Actin 
A

\section{C}

Without Adjuvant Chemotherapy $(n=233)$

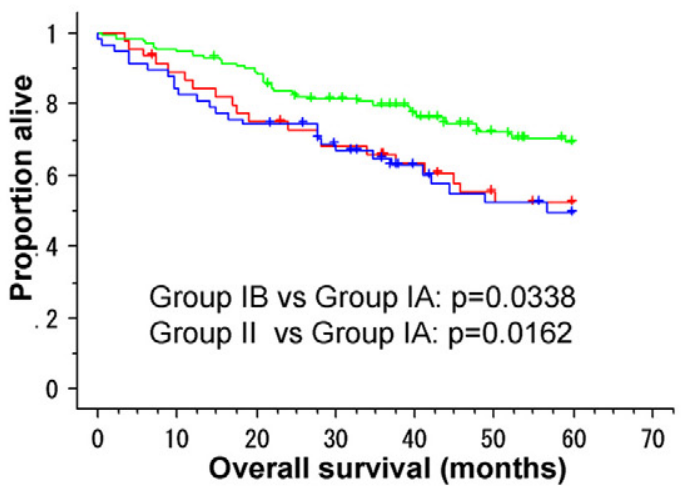

B

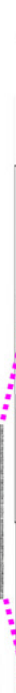

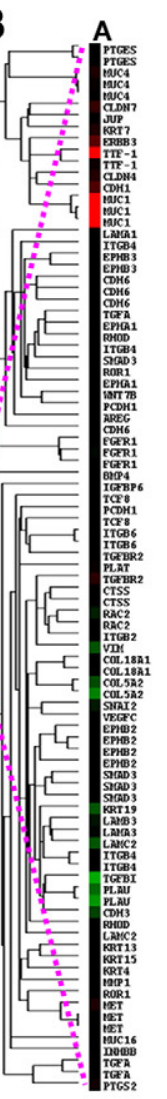

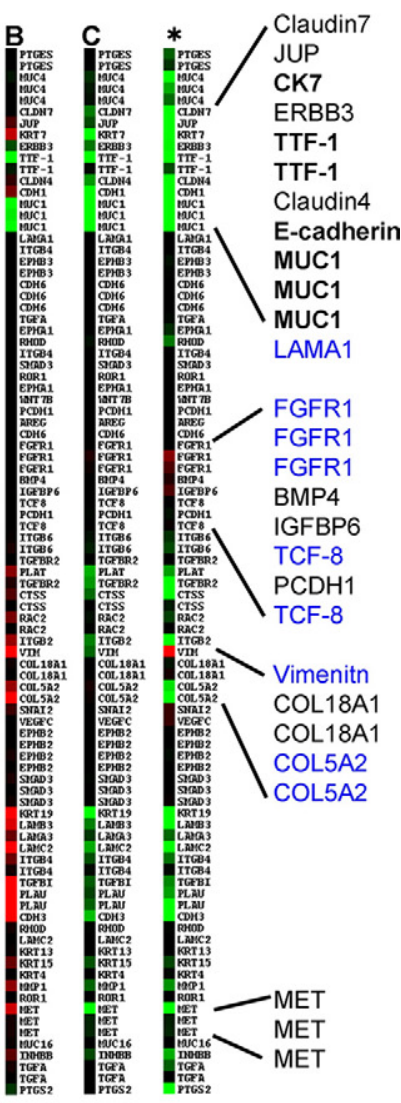

With Adjuvant Chemotherapy $(n=89)$
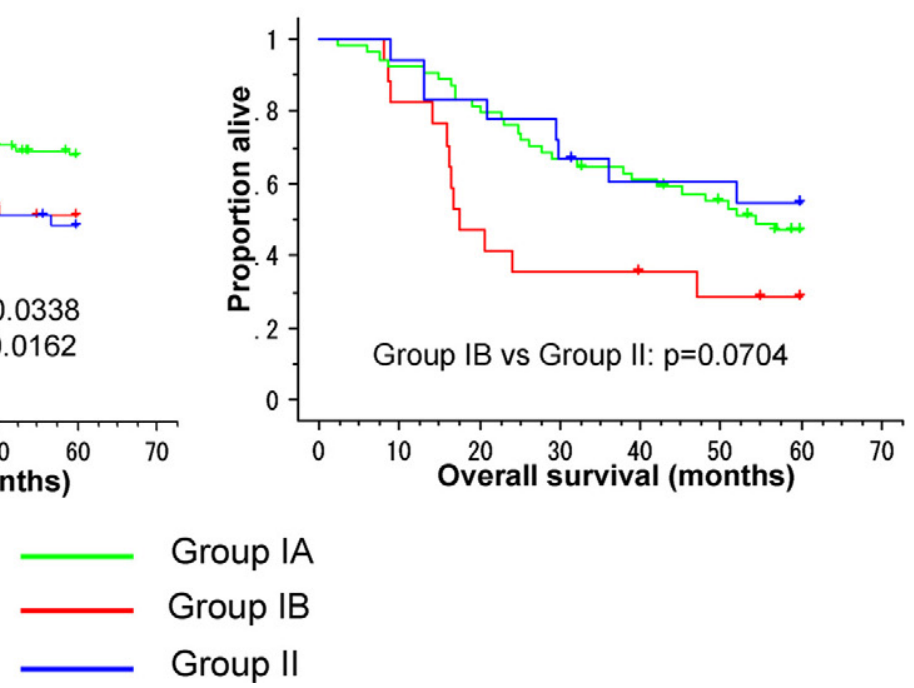

Figure 4. Analysis of publicly available data of 442 primary lung adenocarcinoma cases. A: Hierarchical cluster analysis using the genes selectively expressed in bronchial epithelial phenotype and nonbronchial epithelial phenotype. B: Cluster A showed high expression of terminal bronchial epithelial markers (CK7, TTF-1, and E-cadherin), whereas Cluster B showed modest expression of bronchial epithelial markers (CK7, TTF-1, and E-cadherin) and high expression of a subset of genes (u-PA, P-cadherin, LAMB3, LAMC2, ITGB4, etc) that is associated with cancer cell invasion (see Discussion). In contrast, Cluster C showed very low expression of both bronchial epithelial markers and cancer invasion-associated genes that characterized Group I. The genes selectively expressed in Group II were not clustered together. However, this is due to stromal contamination in primary tumors, as evidenced by the high expression of FGFR1 and vimentin in normal control lung tissue (asterisk). C: Patient survival curves of Group IA (green line), Group IB (red line), and Group II (blue line). Patients without adjuvant chemotherapy (left panel), and those with adjuvant chemotherapy (right panel) were separately analyzed.

genes that characterized Group I (Figure 4B). Thus, Cluster $\mathrm{C}$ represents primary lung adenocarcinomas that correspond to Group II. In this analysis of primary tumors, the genes selectively expressed in Group II were not clustered together. However, this is due to stromal con- tamination in primary tumors, as evidenced by the high expression of FGFR1 and vimentin in normal control lung tissue (Figure 4B).

We examined the correlations between the groups defined by gene expression patterns (Group IA, Group 
Table 4. Correlations between Clinicopathological Factors and Groups Defined by Gene Expression Pattern

\begin{tabular}{|c|c|c|c|c|c|}
\hline Clinical feature & $n$ & Group IA & Group IB & Group II & $P$ value \\
\hline \multicolumn{6}{|c|}{ Pathological T stage (UICC fifth ed.) } \\
\hline T1/T2 & 401 & 227 & 89 & 85 & Group IB versus Group IA: 0.0057 \\
\hline T3 & 28 & 9 & 11 & 8 & Group II versus Group IA: 0.1193 \\
\hline T4 & 12 & 4 & 5 & 3 & Group II versus Group IB: 0.3333 \\
\hline \multicolumn{6}{|c|}{ Nodal involvement (UICC fifth ed.) } \\
\hline pNO & 299 & 171 & 65 & 63 & NS \\
\hline pN1 & 88 & 41 & 22 & 25 & \\
\hline pN2 & 53 & 27 & 18 & 8 & \\
\hline \multicolumn{6}{|c|}{ Pathological stage (UICC fifth ed.) } \\
\hline Stage IA & 114 & 65 & 27 & 22 & Group IB versus Group IA: 0.0123 \\
\hline Stage IB & 162 & 98 & 32 & 32 & Group II versus Group IA: 0.0750 \\
\hline Stage IIA & 24 & 15 & 5 & 4 & Group II versus Group IB: 0.5772 \\
\hline Stage IIB & 71 & 31 & 14 & 26 & \\
\hline Stage IIIA & 57 & 26 & 22 & 9 & \\
\hline Stage IIIB & 12 & 4 & 5 & 3 & \\
\hline \multicolumn{6}{|l|}{ Differentiation } \\
\hline Well & 60 & 50 & 5 & 5 & Group IB versus Group IA: $<0.0001$ \\
\hline Moderate & 209 & 133 & 46 & 30 & Group II versus Group IA: $<0.0001$ \\
\hline Poor & 166 & 56 & 54 & 56 & Group II versus Group IB: 0.2979 \\
\hline \multicolumn{6}{|r|}{ Group IB versus Group IA: 0.0086} \\
\hline Never smoked & 49 & 40 & 5 & 4 & Group II versus Group IA: 0.0015 \\
\hline Smoker & 300 & 158 & 64 & 78 & Group II versus Group IB: 0.7177 \\
\hline
\end{tabular}

IB, and Group II) and clinicopathological factors (Table 4). T-stage was significantly higher in Group IB than Group IA (Group IB versus Group IA: $P=0.0057$ ). Pathological stage was significantly higher in Group IB than Group IA (Group IB versus Group IA: $P=0.0123$ ). Histologically, Group IB and Group II showed significantly poorer differentiation than Group IA (Group IB versus Group IA: $P<0.0001$, Group II versus Group IA: $P<$ $0.0001)$. The ever-smoker rates were significantly higher in Group IB and Group II than in Group IA (Group IB versus Group IA: $P=0.0086$, Group II versus Group IA: $P=0.0015)$. Figure $4 \mathrm{C}$ shows the 5-year survival curves for Group IA, Group IB, and Group II without adjuvant chemotherapy (left panel) and with adjuvant chemotherapy (right panel). Among the cases without adjuvant chemotherapy, Group IB and Group II showed almost the same survival curves as each other and significantly poorer prognosis than Group IA (Group IB versus Group IA, $P=0.0332$; Group II versus Group IA, $P=0.0162$; Wilcoxon method). The relatively favorable prognosis of Group IA may explain why this group is underrepresented in cell lines. Among the patients who received adjuvant therapy, however, the Group II patients showed a better prognosis than the Group IB patients $(P=$ 0.0704, Wilcoxon method). It thus appeared that Group II was more sensitive to chemotherapy than Group I.

\section{Sensitivities of 40 Lung Cancer Cell Lines to Gefitinib, Cisplatin, and Paclitaxel}

Finally, we examined the sensitivities to gefitinib, cisplatin, and paclitaxel in a panel of 40 non-small cell lung cancer cell lines classified into Group I and Group II (Figure 5A). A high sensitivity to gefitinib was observed in the EGFR-mutated and EGFR-amplified cancer cells, while less pronounced but appreciable sensitivities to gefitinib were observed in a MET-amplified cell line (L27) and HER2-amplified cell line (Calu3). A close examination of the responses of KRAS-mutated cancer cells to cisplatin and gefitinib (Figure 5A) revealed that the KRAS-mutated Group I cancer cells (H2009, LC-Ad-1, LC-Ad-2, H441, and H358) were more sensitive to gefitinib and more resistant to cisplatin than the KRASmutated Group II cancer cells (HLC-1, H650, Lu65, A549, $\mathrm{H} 23$, and $\mathrm{H} 460$ ). In comparing the IC 50 values for cisplatin and gefitinib between Group I and Group II, we found that the Group II cancer cells were significantly more sensitive to cisplatin ( $P=0.0115$, Mann-Whitney $U$-test) and more resistant to gefitinib than the Group I cancer cells ( $P=0.0017$, Mann-Whitney U-test) (Figure $5, B$ and C). Paclitaxel was relatively effective against most of the cell lines of Group I and Group II at low concentration $(0.1 \mu \mathrm{mol} / \mathrm{L})$, but four cell lines (PC3, PC14, Calu3, and H1781) from Group I were highly resistant to paclitaxel. Of these four cell lines, two (PC3 and PC14) harbored EGFR mutation and the other two, Calu3 and H1781, harbored HER2 amplification and HER2 mutation, respectively (Figure $5 \mathrm{~A}$ ).

\section{Discussion}

In this study, we began by examining the expression and activation levels of EGFR and MET in a panel of cell lines of lung adenocarcinoma. After comparing EGFR and MET activation, we compared the respective levels of activation with our results on EGFR mutation and MET amplification. While EGFR and MET were highly activated in cell lines with EGFR mutation and MET amplification, respectively, these gene abnormalities were not the sole determinants of the activation status of these two receptors. As reported for EGFR mutation and RAS mutation, 5,6 MET amplification had a mutually exclusive relationship with EGFR and KRAS mutations. Importantly, we found an 
A
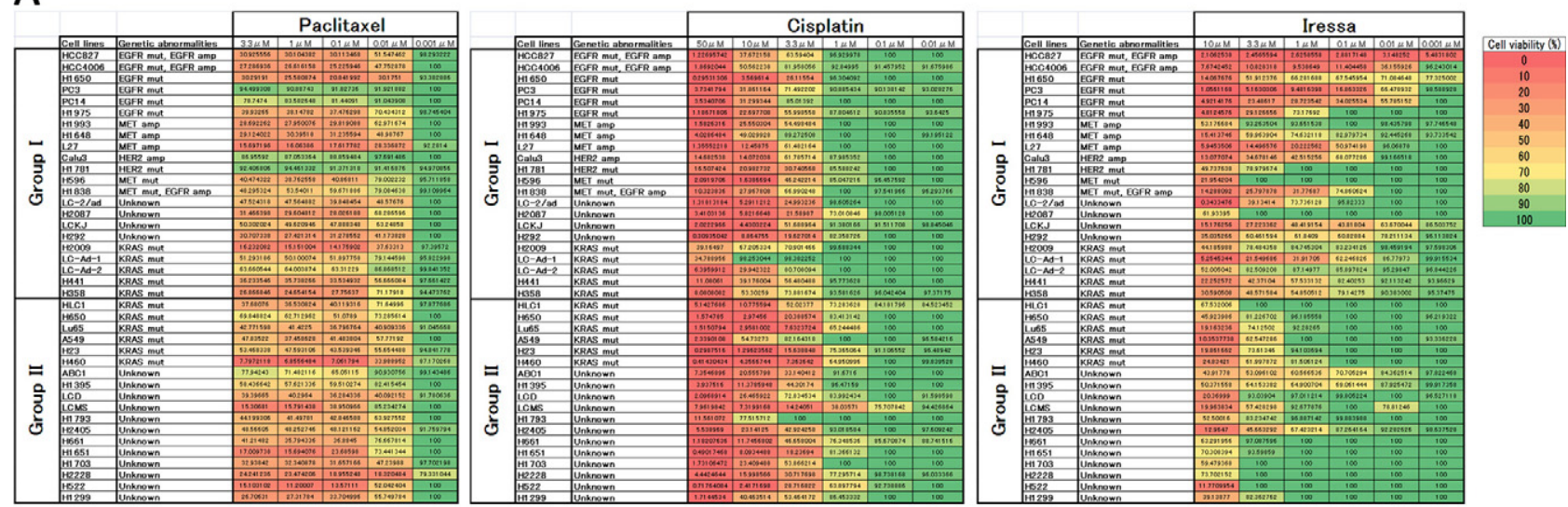

B

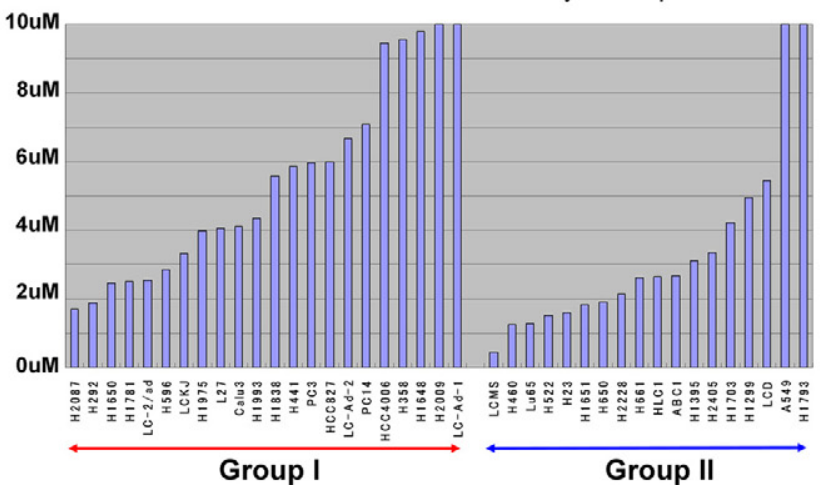

C The IC50 values for cell sensitivity to Gefitinib

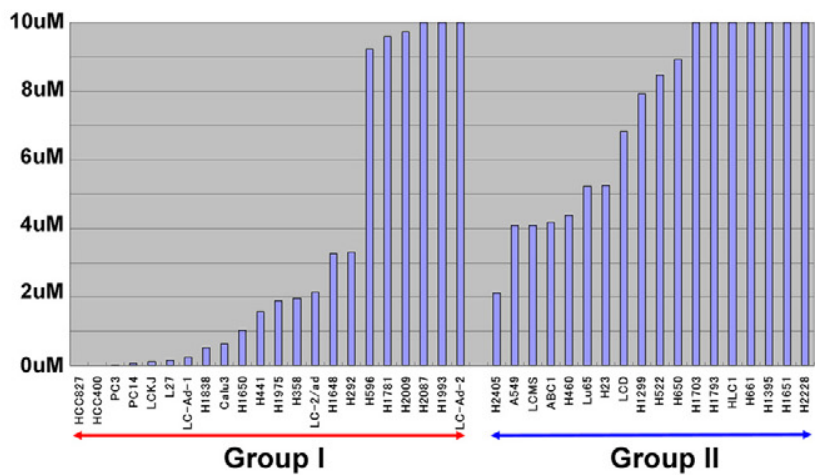

Figure 5. A. Sensitivities of 40 lung cancer cell lines to paclitaxel (left), cisplatin (middle), and gefitinib (right). The viability of cells with each concentration is shown by color gradation (color scale is shown in extreme right panel). Paclitaxel was relatively effective against most of the cell lines at $0.1 \mu$ mol/L, but four cell lines (PC3, PC14, Calu3, and H1781), belonging to Group I, were resistant even at high concentration. Cisplatin needed higher concentration to be effective as compared with paclitaxel. Cisplatin was more effective against Group II than Group I at about $1 \mu$ mol/L. Gefitinib was more effective against Group I than Group II at any concentration tested. It was also of note that KRAS-mutated Group I cell lines were more sensitive to gefitinib than KRAS-mutated Group II cell lines. B and C: Comparisons of the $\mathrm{IC}_{50}$ values for cisplatin $(\mathbf{B})$ and gefitinib $(\mathbf{C})$ between Group I and Group II cell lines. Group II cancer cells were more sensitive to cisplatin than Group I cancer cells $(\mathbf{B}, P=0.0115$, Mann-Whitney $U$-test). Group I cancer cells were more sensitive to gefitinib than Group II cancer cells (C, $P=0.0017$, Mann-Whitney $U$-test). Upper-limit values of the graphs are set to be $10 \mu \mathrm{mol} / \mathrm{L}$.

extensive overlap between EGFR activation and MET activation, a finding which suggests that the cell lines manifesting EGFR and MET activation may constitute a distinct subgroup among the lung adenocarcinoma cells. On detecting high levels of EGFR and MET activation in two cell lines negative for TTF-1 expression, we set out to see if there were other markers that could help to define this distinct group of cell lines with EGFR and MET activation. We found, as a result, that lung adenocarcinoma cells with high EGFR and MET activation can be categorized as bronchial epithelial type or Group I; this type of tumors characteristically express the histopathological markers (TTF-1, CK7, and MUC1) and several gene products frequently involved in cancer cell invasion (integrin beta6, P-cadherin, urokinase-type plasminogen activator, Cox-2, and laminin gamma2). According to a hierarchical cluster analysis, Group I and Group II largely corresponded to bronchial epithelial and nonbronchial epithelial types, respectively, just as we had designated at the outset of this study. Earlier papers have proposed that lung adenocarcinoma can be classified into TRU type and non-TRU type, mainly based on the expression of TTF-1. ${ }^{9}$ According to our classification, Group I defines a subset of lung adenocarcinomas which includes TRU type in addition to non-TRU type tumors with high expression of bronchial epithelial markers such as CK7 and MUC1. With regard to genetic correlation, a significantly higher frequency of EGFR mutation is observed in the $T R U$ type than in the non-TRU type. The relationship between TRU-type tumors and MET abnormalities remains unclear, however. We propose that our classification better reflects genetic abnormalities and activation profiles of EGFR and MET, as has been shown in this study.

The extensive overlap between the activation profiles of EGFR and MET raises several intriguing questions. What is the molecular basis for this overlap? Could it be attributable to cross talk between these two tyrosine kinase receptors on the cell surface? To answer these questions we tested the effects of PHA665752 (MET inhibitor) and CL387,785 (dual EGF/HER2 inhibitor) on phospho-MET and phospho-EGFR in three representative cell lines harboring genetic abnormalities of EGFR, MET or HER2. PHA665752 suppressed both phosphoMET and phospho-EGFR in a MET-amplified cell line but not in EGFR-mutated or HER2-amplificed cell lines. Con- 
versely, CL387,785 suppressed both phospho-MET and phospho-EGFR in EGFR-mutated or HER2-amplificed cell lines, but not in a MET-amplified cell line. These results suggested that cross talk between MET and EGFR may occur in a reciprocal manner, and that the co-activation of EGFR and MET may be caused by the genetic abnormalities of EGFR, MET or HER2 in some Group I cell lines. CL387,785 suppressed MET expression as well as phospho-MET expression, suggesting that EGFR activation leads to increased transcription of the MET gene in addition to MET activation. In fact, two recent papers point to the presence of an activation network involving MET and EGFR. ${ }^{38,39}$ Specifically, these papers have shown that MET activation leads to increased gene transcription and secretion of two EGFR ligands, transforming growth factor- $\alpha$ and heparin-binding epidermal growth factor, which in turn activates EGFR. Conversely, studies in mutant cell lines HCC827 and H3255 by Guo et $\mathrm{a}^{40}$ have shown that MET is highly phosphorylated and co-immunoprecipitated with mutant EGFR, and that the expression and phosphorylation of MET decreases following treatment with gefitinib. They also noted an extensive overlap in the phosphoproteome profiles between EGFR mutant lung adenocarcinoma cell lines and the MET-amplified gastric cell line MKN45. ${ }^{40}$

In this study, we sought to determine gene expression patterns capable of characterizing the biological properties of the cells lines known to overexpress and activate EGFR and MET. Several overexpressed genes of possible biological relevance were identified in the Group I cell lines: MET, HER3, integrin beta6, E-cadherin and P-cadherin, Cox-2, and laminin-5 gamma2 chain. In contrast, Group II was characterized by overexpression of vimentin, FGFR1, and TCF8. In cell lines with MET amplification, MET associates with HER3, an adapter molecule for downstream signaling ${ }^{41}$ Integrin beta6 forms a $\beta$ subunit of $\alpha(\mathrm{v})$ beta6 integrin, which plays a critical role in the activation of transforming growth factor- $\beta .^{42}$ E-cadherin and P-cadherin are involved in homophilic cell adhesion in epithelial cells. A loss of E-cadherin is a hallmark of epithelial-mesenchymal transition, a process implicated in cell invasion and metastasis of many epithelial malignancies. ${ }^{43}$ The significance of P-cadherin expression in cancer is less understood. Studies have shown the upregulation of $\mathrm{P}$-cadherin during wound healing and the early stages of colon cancer, but the expression of this molecule seems to disappear in poorly differentiated tumors. ${ }^{44}$ P-cadherin has also been reported to promote the motility of pancreas cancer, ${ }^{45}$ and its expression is an indicator of poor outcome in breast cancer. ${ }^{46} \mathrm{Cox}-2$ is a rate-limiting enzyme in the production of prostaglandins. ${ }^{23}$ Overexpression of cox-2 in cancer has been reported in numerous studies, and the enzyme plays an important role in tumor angiogenesis and survival. ${ }^{23} \mathrm{u}-\mathrm{PA}$ and laminin-5 gamma2 chain are molecular markers frequently overexpressed at the invasive front lines of cancer. ${ }^{47}$ Cox-2 and laminin-5 gamma2 chains are up-regulated by activation of EGFR and MET. ${ }^{22}$ MUC1 regulates the expression of EGFR and modulates transforming growth factor- $\alpha$ /EGFR-dependent cancer progression. ${ }^{48,49}$ Taken together, these data suggest that the cell lines with high levels of EGFR and MET activation (Group I) rely on this set of molecules (MET, EGFR, HER3, integrin beta6, E-cadherin and P-cadherin, Cox-2, laminin-5 gamma2 chain) for their malignant properties (eg, cell proliferation, migration, and metastasis). Supplemental Figure S3 at http://ajp.amjpathol.org illustrates these regulatory networks operating in the Group I cell lines. In contrast, cell lines without EGFR and MET overexpression (Group II) are characterized by an overexpression of vimentin, a classical marker of epithelial-mesenchymal transition, and they may rely on molecules other than MUC1, Cox-2, integrin beta6, etc for their malignant behaviors. These features of Group I and II cancer cells may need to be considered in the planning of molecular target therapies for the various types of lung adenocarcinoma.

In this study we further investigated the sensitivities of Group I and Group II cancer cells to gefitinib, cisplatin, and paclitaxel. Group I cancer cells were more sensitive to gefitinib, but more resistant to cisplatin, than Group II cancer cells. As we expected, EGFR-mutated or EGFRamplified cancer cells were highly sensitive to gefitinib. The KRAS mutation appeared in both Group I and Group II. And intriguingly, the KRAS-mutated Group I cancer cells were more sensitive to gefitinib than the KRASmutated Group II cancer cells. This suggests that our classification will be useful to extract a subset of KRASmutated lung cancer cases against which gefitinib can be effective. It may be that the KRAS mutation is somewhat less strong than MET amplification or EGFR mutation as a growth driver, and that the maintenance of optimal cell growth and survival in KRAS-mutated Group I cell lines depends on not only the oncogenic mutant KRAS, but also MET activation or EGFR activation. We have recently reported that KRAS-mutated cell lines with high levels of phospho-MET were modestly sensitive to PHA665752, while KRAS-mutated cell lines with low levels of phospho-MET were wholly resistant to PHA665752. ${ }^{50}$ The differences of biological properties and drug sensitivity between KRAS-mutated Group I cell lines and KRAS-mutated Group II cell lines may be explained by additional genetic abnormalities acquired in the latter. This hypothesis will be tested in future studies.

Paclitaxel was effective against most of the 40 cell lines at low concentration, but four Group I cancer cells harboring EGFR mutation, HER2 amplification or HER2 mutation were quite resistant to paclitaxel. Group I cancer cells frequently harbored genetic abnormalities of EGFR, MET, and HER2. Three MET-amplified lung adenocarcinoma cell lines (H1648, H1993, and L27) also belonged to Group I, and these lines were quite sensitive to the MET inhibitor PHA665752. ${ }^{50}$ On this basis, we believe that molecular-targeted therapy against these strong growth drivers should be the first line of treatment for Group I lung cancer cases. Chemotherapy should be the first line of treatment for Group II cases, unless strong growth drivers of the cancers are revealed.

Our classification will be applicable to lung adenocarcinomas from both Japanese and Western populations. An analysis of primary adenocarcinomas from four institutions in the United States has validated the classification, and lung adenocarcinomas surgically resected at 
Jichi University Hospital are also classifiable into Group I or Group II according to the expression levels of MET, TTF-1, laminin-5, Cox-2, etc (unpublished observation). Yet the ratio of Group I to Group II in our institution was higher than in the four institutions in the United States (not published). One possible explanation for this may be the higher frequency of EGFR mutations in the lung adenocarcinomas of East-Asians compared to those of other ethnic groups. ${ }^{51}$ Our classification may also be useful for elucidating the discrepancies in the prognostic factors found among different institutions and geographical areas. The different proportions of Group I and Group II will influence the prognostic significance of some molecular biomarkers. Cox-2 and laminin-5, for example, will be assessed as unfavorable prognostic factors in Group I, but not in Group II. This hypothesis will be tested in future studies.

In summary, we have shown that co-activation of EGFR and MET defines a distinct subgroup of lung carcinoma with characteristic genetic abnormalities, gene expression pattern, and response to chemotherapeutic reagents. We propose that this classification based on integrated information on EGFR and MET abnormalities will not only be useful for the understanding of the biological properties of lung adenocarcinoma, but also for the clinical decision making between molecular-targeted therapy and chemotherapy.

\section{References}

1. Statistics and Information Department. Vital Statistics, 2000. Tokyo: Ministry of Health, Labor, and Welfare, 2001

2. Jemal A, Siegel R, Ward E, Murray T, Xu J, Smigal C, Thun MJ. Cancer Statistics, 2006. CA Cancer J Clin 2006, 56:106-130

3. Naruke T, Tsuchiya R, Kondo H, Asamura H: Prognosis and survival after resection for bronchogenic carcinoma based on the 1997 TNMstaging classification: the Japanese experience. Ann Thorac Surg 2001, 71:1759-1764

4. Janssen-Heijnen ML, Coebergh JW: Trends in incidence and prognosis of the histological subtypes of lung cancer in North America. Australia, New Zealand and Europe. Lung Cancer 2001, 31:123-137

5. Riely GJ, Politi KA, Miller VA, Pao W: Update on epidermal growth factor receptor mutations in non-small cell lung cancer. Clin Cancer Res 2006, 12:7232-7241

6. Mitsudomi T, Yatabe Y: Mutations of the epidermal growth factor receptor gene and related genes as determinants of epidermal growth factor receptor tyrosine kinase inhibitors sensitivity in lung cancer. Cancer Sci 2007, 98:1817-1824

7. Yokota J, Kohno T: Molecular footprints of human lung cancer progression. Cancer Sci 2004, 95:197-204

8. Yatabe Y, Mitsudomi T: Epidermal growth factor receptor mutations in lung cancers. Pathol Int 2007, 57:233-244

9. Takeuchi T, Tomida S, Yatabe Y, Kosaka T, Osada H, Yanagisawa K, Mitsudomi T, Takahashi T: Expression profile-defined classification of lung adenocarcinoma shows close relationship with underlying major genetic changes and clinicopathologic behaviors. J Clin Oncol 2006, 24:1679-1688

10. Motoi N, Szoke J, Riely GJ, Seshan VE, Kris MG, Rusch VW, Gerald WL, Travis WD: Lung adenocarcinoma: modification of the 2004 WHO mixed subtype to include the major histologic subtype suggests correlations between papillary and micropapillary adenocarcinoma subtypes. EGFR mutations and gene expression analysis. Am J Surg Pathol 2008, 32:810-827

11. Ninomiya H, Hiramatsu M, Inamura K, Nomura K, Okui M, Miyoshi T, Okumura S, Satoh Y, Nakagawa K, Nishio M, Horai T, Miyata S, Tsuchiya E, Fukayama M, Ishikawa Y: Correlation between morphol- ogy and EGFR mutations in lung adenocarcinomas Significance of the micropapillary pattern and the hobnail cell type. Lung Cancer 2009, 63:235-240

12. Miyoshi T, Satoh Y, Okumura S, Nakagawa K, Shirakusa T, Tsuchiya E, Ishikawa Y: Early-stage lung adenocarcinomas with a micropapillary pattern, a distinct pathologic marker for a significantly poor prognosis. Am J Surg Pathol 2003, 27:101-109

13. Amin MB, Tamboli P, Merchant SH, Ordóñez NG, Ro J, Ayala AG, Ro $J Y$ : Micropapillary component in lung adenocarcinoma: a distinctive histologic feature with possible prognostic significance. Am J Surg Pathol 2002, 26:358-364

14. Sakuma $Y$, Matsukuma S, Yoshihara M, Nakamura $Y$, Noda K, Nakayama H, Kameda Y, Tsuchiya E, Miyagi Y: Distinctive evaluation of nonmucinous and mucinous subtypes of bronchioloalveolar carcinomas in EGFR and K-ras gene-mutation analyses for Japanese lung adenocarcinomas: confirmation of the correlations with histologic subtypes and gene mutations. Am J Clin Pathol 2007, 128:100-108

15. De Oliveira Duarte Achcar R, Nikiforova MN, Yousem SA: Micropapillary lung adenocarcinoma: eGFR, K-ras, and BRAF mutational profile. Am J Clin Pathol 2009, 131:694-700

16. Takanami I, Tanana F, Hashizume $T$, Kikuchi $K$, Yamamoto $Y$, Yamamoto T, Kodaira S: Hepatocyte growth factor and c-Met/hepatocyte growth factor receptor in pulmonary adenocarcinomas: an evaluation of their expression as prognostic markers. Oncology 1996, 53:392-397

17. Tsao MS, Liu N, Chen JR, Pappas J, Ho J, To C, Viallet J, Park M, Zhu $\mathrm{H}$ : Differential expression of Met/hepatocyte growth factor receptor in subtypes of non-small cell lung cancers. Lung Cancer 1998, 20:1-16

18. Masuya D, Huang C, Liu D, Nakashima T, Kameyama K, Haba R, Ueno $\mathrm{M}$, Yokomise $\mathrm{H}$ : The tumour-stromal interaction between intratumoral c-Met and stromal hepatocyte growth factor associated with tumour growth and prognosis in non-small-cell lung cancer patients. Br J Cancer 2004, 90:1555-1562

19. Nakamura Y, Niki T, Goto A, Morikawa T, Miyazawa K, Nakajima J, Fukayama M: c-Met activation in lung adenocarcinoma tissues: an immunohistochemical analysis. Cancer Sci 2007, 98:1006-1013

20. Nakamura Y, Matsubara D, Goto A, Ota S, Sachiko O, Ishikawa S, Aburatani H, Miyazawa K, Fukayama M, Niki T: Constitutive activation of c-Met is correlated with c-Met overexpression and dependent on cell-matrix adhesion in lung adenocarcinoma cell lines. Cancer Sci 2008, 99:14-22

21. Takano T, Ohe $Y$, Sakamoto H, Tsuta K, Matsuno $Y$, Tateishi U, Yamamoto S, Nokihara H, Yamamoto N, Sekine I, Kunitoh H, Shibata T, Sakiyama T, Yoshida T, Tamura T: Epidermal growth factor receptor gene mutations and increased copy numbers predict gefitinib sensitivity in patients with recurrent non-small-cell lung cancer. J Clin Oncol 2005, 23:6829-6837

22. Niki T, Kohno T, Iba S, Moriya Y, Takahashi Y, Saito M, Maeshima A Yamada T, Matsuno Y, Fukayama M, Yokota J, Hirohashi S: Frequent co-localization of Cox-2 and laminin-5 gamma2 chain at the invasive front of early-stage lung adenocarcinomas. Am J Pathol 2002, 160:1129-1141

23. Wang MT, Honn KV, Nie D: Cyclooxygenases, prostanoids, and tumor progression. Cancer Metastasis Rev 2007, 26:525-534

24. Lynch TJ, Bell DW, Sordella R, Gurubhagavatula S, Okimoto RA Brannigan BW, Harris PL, Haserlat SM, Supko JG, Haluska FG, Louis DN, Christiani DC, Settleman J, Haber DA: Activating mutations in the epidermal growth factor receptor underlying responsiveness of nonsmall-cell lung cancer to gefitinib. N Engl J Med 2004, 350:2129-2139

25. Ishii M, Hashimoto S, Tsutsumi S, Wada Y, Matsushima K, Kodama T, Aburatani H: Direct comparison of GeneChip and SAGE on the quantitative accuracy in transcript profiling analysis. Genomics 2000, 68:136-143

26. Midorikawa $\mathrm{Y}$, Yamamoto $\mathrm{S}$, Ishikawa $\mathrm{S}$, Kamimura $\mathrm{N}$, Igarashi $\mathrm{H}$, Sugimura $H$, Makuuchi M, Aburatani $H$ : Molecular karyotyping of human hepatocellular carcinoma using single-nucleotide polymorphism arrays. Oncogene 2006, 25:5581-5590

27. Wang T, Niki T, Goto A, Ota S, Morikawa T, Nakamura Y, Ohara E, Ishikawa S, Aburatani H, Nakajima J, Fukayama M: Hypoxia increases the motility of lung adenocarcinoma cells A549 via activation of the epidermal growth factor receptor pathway. Cancer Sci 2007, 98:506-511

28. Ishikawa S, Komura D, Tsuji S, Nishimura K, Yamamoto S, Panda B, 
Huang J, Fukayama M, Jones KW, Aburatani H: Allelic dosage analysis with genotyping microarrays. Biochem Biophys Res Commun 2005, 333:1309-1314

29. Coulombe PA, Omary MB: 'Hard' and 'soft' principles defining the structure, function and regulation of keratin intermediate filaments. Curr Opin Cell Biol 2002, 14:110-122

30. Moniaux N, Escande F, Porchet N, Aubert JP, Batra SK: Structural organization and classification of the human mucin genes. Front Biosci 2001, 6:D1192-D1206

31. Inamura K, Satoh Y, Okumura S, Nakagawa K, Tsuchiya E, Fukayama M, Ishikawa Y: Pulmonary adenocarcinomas with enteric differentiation: histologic and immunohistochemical characteristics compared with metastatic colorectal cancers and usual pulmonary adenocarcinomas. Am J Surg Pathol 2005, 29:660-665

32. Rossi G, Marchioni A, Milani M, Scotti R, Foroni M, Cesinaro A, Longo L, Migaldi M, Cavazza A: TTF-1, cytokeratin 7, 34betaE12, and CD56/ NCAM immunostaining in the subclassification of large cell carcinomas of the lung. Am J Clin Pathol 2004, 122:884-893

33. Tsuta K, Ishii G, Nitadori J, Murata Y, Kodama T, Nagai K, Ochiai A: Comparison of the immunophenotypes of signet-ring cell carcinoma, solid adenocarcinoma with mucin production, and mucinous bronchioloalveolar carcinoma of the lung characterized by the presence of cytoplasmic mucin. J Pathol 2006, 209:78-87

34. Garber ME, Troyanskaya OG, Schluens K, Petersen S, Thaesler Z, Pacyna-Gengelbach M, van de Rijn M, Rosen GD, Perou CM, Whyte RI, Altman RB, Brown PO, Botstein D, Petersen I: Diversity of gene expression in adenocarcinoma of the lung. Proc Natl Acad Sci USA 2001, 98:13784-13789

35. Bhattacharjee A, Richards WG, Staunton J, Li C, Monti S, Vasa P, Ladd C, Beheshti J, Bueno R, Gillette M, Loda M, Weber G, Mark EJ, Lander ES, Wong W, Johnson BE, Golub TR, Sugarbaker DJ, Meyerson M: Classification of human lung carcinomas by mRNA expression profiling reveals distinct adenocarcinoma subclasses. Proc Natl Acad Sci USA 2001, 98:13790-13795

36. Agarwal S, Zerillo C, Kolmakova J, Christensen JG, Harris LN, Rimm DL, Digiovanna MP, Stern DF: Association of constitutively activated hepatocyte growth factor receptor (Met) with resistance to a dual EGFR/Her2 inhibitor in non-small-cell lung cancer cells. $\mathrm{Br} \mathrm{J}$ Cancer 2009, 100:941-949

37. Shedden K, Taylor JM, Enkemann SA, Tsao MS, Yeatman TJ, Gerald WL, Eschrich S, Jurisica I, Giordano TJ, Misek DE, Chang AC, Zhu CQ, Strumpf D, Hanash S, Shepherd FA, Ding K, Seymour L, Naoki K, Pennell N, Weir B, Verhaak R, Ladd-Acosta C, Golub T, Gruidl M, Sharma A, Szoke J, Zakowski M, Rusch V, Kris M, Viale A, Motoi N, Travis W, Conley B, Seshan VE, Meyerson M, Kuick R, Dobbin KK, Lively T, Jacobson JW, Beer DG: Gene expression-based survival prediction in lung adenocarcinoma: a multi-site, blinded validation study. Nat Med 2008, 14:822-827

38. Reznik TE, Sang Y, Ma Y, Abounader R, Rosen EM, Xia S, Laterra J: Transcription-dependent epidermal growth factor receptor activation by hepatocyte growth factor. Mol Cancer Res 2008, 6:139-150
39. Siegfried JM, Gubish CT, Rothstein ME, Queiroz de Oliveira PE, Stabile LP: Signaling pathways involved in cyclooxygenase-2 induction by hepatocyte growth factor in non small-cell lung cancer. Mol Pharmacol 2007, 72:769-779

40. Guo A, Villén J, Kornhauser J, Lee KA, Stokes MP, Rikova K, Possemato A, Nardone J, Innocenti G, Wetzel R, Wang $Y$, MacNeill J, Mitchell J, Gygi SP, Rush J, Polakiewicz RD, Comb MJ: Signaling networks assembled by oncogenic EGFR and c-Met. Proc Natl Acad Sci USA 2008, 105:692-697

41. Engelman JA, Zejnullahu K, Mitsudomi T, Song Y, Hyland C, Park JO, Lindeman N, Gale CM, Zhao X, Christensen J, Kosaka T, Holmes AJ, Rogers AM, Cappuzzo F, Mok T, Lee C, Johnson BE, Cantley LC, Jänne PA: MET amplification leads to gefitinib resistance in lung cancer by activating ERBB3 signaling. Science 2007, 316:1039-1043

42. Koth LL, Alex B, Hawgood S, Nead MA, Sheppard D, Erle DJ, Morris DG: Integrin beta6 mediates phospholipid and collectin homeostasis by activation of latent TGF-beta1. Am J Respir Cell Mol Biol 2007, 37:651-659

43. Hirohashi S, Kanai Y: Cell adhesion system and human cancer morphogenesis. Cancer Sci 2003, 94:575-581

44. Sanders DS, Perry I, Hardy R, Jankowski J: Aberrant P-cadherin expression is a feature of clonal expansion in the gastrointestinal tract associated with repair and neoplasia. J Pathol 2000, 190:526-530

45. Taniuchi $\mathrm{K}$, Nakagawa $\mathrm{H}$, Hosokawa M, Nakamura T, Eguchi $\mathrm{H}$, Ohigashi H, Ishikawa O, Katagiri T, Nakamura Y: Overexpressed P-cadherin/CDH3 promotes motility of pancreatic cancer cells by interacting with p120ctn and activating rho-family GTPases. Cancer Res 2005, 65:3092-3099

46. Paredes J, Correia AL, Ribeiro AS, Albergaria A, Milanezi F, Schmitt FC: P-cadherin expression in breast cancer: a review. Breast Cancer Res 2007, 9:214

47. Pyke C, Salo S, Ralfkiaer E, Rømer J, Danø K, Tryggvason K: Laminin-5 is a marker of invading cancer cells in some human carcinomas and is coexpressed with the receptor for urokinase plasminogen activator in budding cancer cells in colon adenocarcinomas. Cancer Res 1995, 55:4132-4139

48. Pochampalli MR, Bitler BG, Schroeder JA: Transforming growth factor alpha dependent cancer progression is modulated by Muc1. Cancer Res 2007, 67:6591-6598

49. LiX, Wang L, Nunes DP, Troxler RF, Offner GD: Suppression of MUC1 synthesis downregulates expression of the epidermal growth factor receptor. Cancer Biol Ther 2005, 4:968-973

50. Matsubara D, Ishikawa S, Oguni S, Aburatani H, Fukayama M, Niki T. Molecular predictors of sensitivity to the MET inhibitor PHA665752 in lung carcinoma cells. J Thorac Oncol 2010, 5:1317-1324

51. Shigematsu H, Lin L, Takahashi T, Nomura M, Suzuki M, Wistuba II, Fong KM, Lee H, Toyooka S, Shimizu N, Fujisawa T, Feng Z, Roth JA, Herz J, Minna JD, Gazdar AF: Clinical and biological features associated with epidermal growth factor receptor gene mutations in lung cancers. J Natl Cancer Inst 2005, 97:339-346 